Erlend Hem (f. 1970) er dr.med. og assisterende sjefredaktør i Tidsskriftet.

\title{
Brysomme studenter
}

Som lærer for medisinstudenter opplever jeg ofte at jeg ikke makter å utnytte deres potensial og engasjement godt nok. Mange synes nok at studiene er krevende og at det er begrenset tid og mulighet til å engasjere seg. Som student tenkte jeg aldri over hvor viktig studentenes engasjement er for universitetslærerne. Etter å ha undervist medisinstudenter i mange år, merker jeg dette godt. Når et kull har flere interesserte studenter som hiver seg frempå med spørsmål og kommentarer underveis i undervisningen, virker det stimulerende både på meg som lærer og på de andre studentene.

At studentene bør engasjere seg i undervisningen, er ofte tema for festtaler ved innledningen av hvert studieår. Hva innebærer det? Nylig førte spørsmålet om gjeninnføring av karakterer til et stort engasjement blant medisinstudenter i Oslo, men studentenes engasjement vakte liten begeistring i fakultetsledelsen (1). At studentengasjement ofte oppleves som brysomt eller upassende, er langt fra nytt. Det stemmer godt blant annet med erfaringene fra en sak som engasjerte studentene for over 30 år siden.

Høsten 1982 startet medisinstudenter i Oslo en debatt om obduksjon med flere artikler i studentbladet Esculap. De hadde titler som Er retten til å nekte obduksjon reell? og Likskjoererpraksis. Studentene mente at det burde kreves eksplisitt samtykke før obduksjon kunne finne sted $(2,3)$. Dersom de pårørende eller pasienten skulle ha reell mulighet til å nekte obduksjon, måtte det gis mer saklig informasjon (4). Det ble det bråk av. Departementet sendte ut et rundskriv, spørsmålet ble tatt opp i Stortingets spørretime, det var hektisk møtevirksomhet mellom departementer, Helsedirektoratet og de medisinske fakultetene (5). Saken ble debattert i massemedier, tidsskrifter og bøker $(2,6)$, og studentene fulgte opp med en spørreundersøkelse blant leger med erfaring i å spørre pårørende om tillatelse til obduksjon (7). Det endte med at myndighetene satte ned et offentlig utvalg (5).

Saken engasjerte patologene. Det er betegnende for temperaturen i debatten at da professor Kristen Arnesen (1918-2005) ble invitert til å skrive et tilsvar til en medisinstudent i Tidsskriftets korrespondansespalte, svarte han: «Jeg har allerede én gang innlatt meg på en meningsutveksling med Torgeir Bruun Wyller. Jeg gjør det nødig flere ganger» (8). Debatten om informert samtykke ved obduksjon har senere gått flere runder (9-11). Poenget her er at det var studentene som tok opp saken, og at den hadde omfattende offentlige ringvirkninger. Det er verdt å minne om dette som eksempel på hva studentengasjement kan føre til.

Ivrige studenter påvirker meg til å yte ekstra som lærer (12). Studentenes engasjement stimulerer meg til å gi stimulerende undervisning. Så enkelt er det: Den beste undervisningen bidrar studentene til selv.

\section{Litteratur}

1. Toft M. - Forsvarar innføring av graderte karakterar på medisin. Uniforum 11.9.2013. www.uniforum.uio.no/nyheter/2013/09/forsvarar-innforing-avkarakterar-pa-medisin.html (15.9.2014)

2. Wyller TB. Obduksjon - i livets tjeneste men hvordan? Kirke og Kultur 1983; 88: $450-7$.

3. Swensen E. Meningsbæreren. Tidsskr Nor Legeforen 2013; 133: 2044-6.

4. Mæhle BO. Betydningen av obduksjonsvirksomheten ved en universitetsklinikk. Tidsskr Nor Lægeforen 1985; 105: 2319-22.

5. Norges offentlige utredninger. Sykehusobduksjon. NOU 1985: 37. www.nb.no/ $\mathrm{nbsok} / \mathrm{nb} / 857 \mathrm{eb} 1 \mathrm{~d} 984927 \mathrm{fae} 2823 \mathrm{~d} 074 \mathrm{e} 1248 \mathrm{eef}$.nbdigital?lang=no\#0 (15.9.2014).

6. Iversen $\mathrm{OH}$, Stendal M, red. Obduksjon: den medisinske unders økelse etter døden. Oslo: Luther forlag, 1985.

7. Wyller TB. Kan man spørre pårørende om tillatelse til obduksjon? Noen legers erfaringer. AEsculap 1984; nr. 4: 8 .

8. Arnesen K. Obduksjon. Tidsskr Nor Lægeforen 1986; 106: 435

9. Pedersen R, Hofmann B. Ny forskrift om obduksjon. Tidsskr Nor Lægeforen 2004; 124: 2791 .

10. Norges offentlige utredninger. Når døden tjener livet: et forslag til nye lover om transplantasjon, obduksjon og avgivelse av lik. NOU 2011: 21.

www.regjeringen.no/nb/dep/hod/dok/nouer/2011/nou-2011-21.html?id=666923 (15.9.2014).

11. Hølen J, Ruyter KW. Presseetikken kom til kort, ikke forskningsetikken. Morgenbladet 24.7.2014. http://morgenbladet.no/debatt/2014/presseetikken_kom til kort ikke forskningsetikken\#.VBVlt6M4VaQ (15.9.2014).

12. Prydz K. Studentenes innsats øker studiekvaliteten. Aftenposten 31.7.2013. www.aftenposten.no/meninger/debatt/Studentenes-innsats-okerstudiekvaliteten-7267885.html (15.9.2014) 